\title{
THE ROLE OF BUILDING TECHNOLOGIES IN REDUCING AND CONTROLLING PEAK ELECTRICITY DEMAND
}

\author{
Jonathan Koomey* and Richard E. Brown, LBNL \\ *Author for Correspondence: JGKoomey@lbl.gov, 510-486-5974 \\ Energy Analysis Department \\ Environmental Energy Technologies Division \\ Ernest Orlando Lawrence Berkeley National Laboratory \\ University of California \\ Berkeley, CA 94720 \\ http://enduse.lbl.gov/projects/peakdemand.html
}

September 2002

This work was supported by the Office of Building Technology, State and Community Programs of the U.S. Department of Energy, under Contract No. DE-AC03-76SF00098. 



\section{TABLE OF CONTENTS}

I. WHY CARE ABOUT PEAK DEMAND? ................................................... 1

II. WHAT ARE THE DRIVERS OF PEAK DEMAND? .......................................... 3

III. WHAT ARE THE KEY PEAK DEMAND ISSUES?............................................. 5

What strategies are used to affect peak demand? ..................................... 5

What policies can be used to affect peak demand? .................................. 8

What are the seasonal aspects of electric peak demand? ......................... 9

What are the geographic components of the issue? ................................ 10

Are there peak demand issues for natural gas? ...................................... 10

What are the key research questions? .................................................. 11

What is the state of data on peak demand in buildings?........................... 12

IV. WHO ARE THE KEY STAKEHOLDERS? ............................................. 13

V. IS THERE A UNIQUE FEDERAL ROLE? ........................................... 14

VI. WHICH POTENTIAL SOLUTIONS FALL UNDER THE PURVIEW OF DOE?........... 14

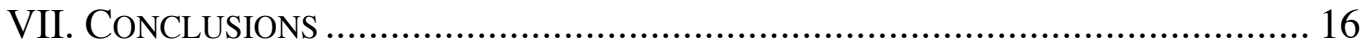

ACKNOWLEDGEMENTS ....................................................................... 16

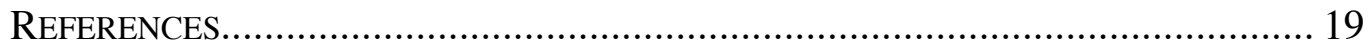




\section{WHY CARE ABOUT PEAK DEMAND?}

Peak demand issues have come to the fore recently because of the California electricity crisis (Borenstein 2001). Uncertainties surrounding the reliability of electric power systems in restructured markets as well as security worries are the latest reasons for such concerns, but the issues surrounding peak demand are as old as the electric utility system itself (Osborn and Kawann 2001). The long lead times associated with building new capacity, the lack of price response in the face of time-varying costs, the large difference between peak demand and average demand, and the necessity for real-time delivery of electricity all make the connection between system peak demand and system reliability an important driver of public policy in the electric utility sector.

This exploratory option paper was written at the request of Jerry Dion at the U.S. Department of Energy (DOE). It is one of several white papers commissioned in 2002 exploring key issues of relevance to DOE. This paper catalogs policy-relevant issues surrounding peak demand but doesn't treat these issues in detail-this task awaits further research.

Electricity demand varies constantly. At times of low demand, only the utility's lowest marginal cost plants operate, while at peak times, almost all of the utility's available power plants must run to meet the demand and prevent system outages. The lowest marginal cost plants are often the most fuel efficient. The electric utility industry has traditionally focused on peak demand because the likelihood of system outages (often measured by the so-called "loss of load probability" or LOLP) is by far the greatest at peak times (Kahn 1988). LOLP is typically concentrated in a relatively small number of hours per year, and those hours are often near the time of system or seasonal peaks.

The reasons why peak times are so likely to be associated with system outages are several-fold:

- Real time delivery: Electricity cannot be cost-effectively stored, and thus must be supplied at the same time that it is being used.

- Long lead times: Generation capacity is fixed in the short term, and adding new capacity can take anywhere from two to ten years, and sometimes longer.

- Lack of responsiveness to real-time costs: Demand is typically not responsive to the cost of supplying power in real time (costs per $\mathrm{kWh}$ at time of system peak can be several times the retail rates charged to customers). These retail rates might vary seasonally, but only rarely are responsive to daily changes in prices, in part due to the widespread lack of inexpensive metering technology capable of charging customers for their electricity use in real time, and an associated lack of end-use device technologies capable of tracking and responding to such timevarying price signals. Even when metering technologies are capable of monitoring such price signals, sometimes the bills are delivered on a monthly basis, thus sidestepping the most powerful potential effect of real-time prices, the immediate behavioral feedback. 
For these reasons, the time of system peak demand has been a preoccupation of utility planners for many years. In addition, utilities are concerned with peak demand because they don't recover all of their costs at peak times, which is not a reliability concern, but a financial one (they are usually made "whole" by utility regulators after the fact, but the cash outflow caused by this lack of immediate cost recovery can sometimes be a problem). Finally, utilities are concerned not just with the system peak demand, but with local and regional peak demands that may result in outages due to local transmission, distribution, and generation constraints (in fact, local outages are far more common than system outages).

Society is rightly concerned about peak demand for other reasons as well:

- Economic efficiency: The utility must have large amounts of generating, transmission, and distribution capacity available for peak times, but this capacity sits idle for most of the year. If electric load curves could be flattened (through efficiency improvements, load management, or responses to time-varying prices) then a more efficient use of society's capital could result. In addition, when the utility system is close to peak, small increases in demand can lead to large increases in marginal costs per $\mathrm{kWh}$, because of the inelasticity of supply at that time.

- Environmental quality: The utility's highest marginal cost plants are run at peak times, even though they can be some of the most inefficient and polluting plants, because the system peak cannot be met without running these plants.

- Fuel security: Many peaking and intermediate load plants are fired by natural gas or (to a lesser extent) fuel oil, raising issues of fuel security (for oil) and diversity/price stability (for natural gas).

- Facility siting: The size of the electricity system roughly scales with peak load, leading to more generating stations, transmission and distribution lines, distribution substations, etc. There is growing resistance in our society (and growing competition from other uses) to using scarce land resources for uses such as the electrical system.

Society's concern about peak demand can be seen more broadly as a need to ensure that supply and demand remain in balance at any instant. As shown by the California power crisis in 2000 and 2001, power outages can occur during even low demand times if insufficient generating capacity is available at those times (Borenstein 2001). Reducing demand at times when the system is in danger of outages can be an effective way to improve utility reliability, both system-wide and locally. The discussion in this paper is applicable to any times when demand threatens to outpace available capacity, whether or not those times occur at time of system peak.

This paper focuses on options on the customer's side of the meter, but there are other possibilities as well. One example is a set of power system optimization algorithms that apparently could have prevented blackouts on June 14, 2001 in the PG\&E service territory (Hope et al. 2001). Other options include building more (or more efficient) 
transmission and distribution capacity, increased use of on-site generation and electricity storage, or targeted use of photovoltaics at key distribution nodes (Shugar 1990). The question for society as a whole is "What is the least-cost method for ensuring that electricity supply and demand remain in balance?" The demand side options need to become an integral part of load planning, just as for energy planning, where they already are widely accepted. Outages, even local ones, are extremely costly for society if they disrupt economic activity, and both supply and demand-side options can help avert them. Focusing just on the supply side will likely lead to a misallocation of society's resources - consumers and businesses will pay more for energy services than necessary.

Peak demand is an important issue to consider when making energy-related decisions or designing energy policies, but there are many other factors to be considered as well. These factors can include occupant comfort and productivity, health and safety, environmental impacts, and national security. Where feasible, peak load strategies should be considered in an integrated framework, because these issues are often interconnected. For example, strategies that increase the thermal efficiency of buildings would affect peak load but might also decrease human health problems and mortality due to summer heat storms. Research is needed on analytical approaches that integrate peak load into multi-criteria decision frameworks.

To avoid confusion and allow accurate comparisons, it is important to define key terms. We use the term electricity use to refer generally to electricity consumption by electricity consumers measured over any time period. This includes both annual consumption (energy) and instantaneous load (power). Peak load is the maximum simultaneous electricity demand for some portion of the electrical system, typically averaged over an hour. It typically is characterized as annual, daily, or seasonal. End-use peak load is measured at the customer's electricity-using equipment. System peak load is measured at the power plant busbar, representing the load served by generating plants. The simultaneous peak load for all end-users (e.g., for an entire utility service territory) is referred to as the coincident peak load. Subgroups of end-users (e.g., all industrial customers) will have their own simultaneous peak load, which is referred to as noncoincident peak load for a sector, locality, or customer class. Many analysts use the terms demand and load interchangeably.

\section{WHAT ARE THE DRIVERS OF PEAK DEMAND?}

Many factors influence peak demand, including weather, demographics, economic activity, equipment ownership, technology choice, usage behavior, designer/installer behavior, and government policies. We treat each of these factors in turn.

- Weather: Weather tends to be the most important driver of peak demand. For utilities in warmer regions of the U.S., peak demand is driven mainly by air conditioning loads on the hottest summer afternoons. For colder regions, peak demand is in the winter, and is driven by the demand for electric heating on the coldest mornings of the year. Some utilities in the middle latitudes of the U.S. have summer and winter peaks of comparable size. 
- Demographics: Demographic trends affect settlement and equipment use patterns. For example, much of the recent growth in the U.S. housing stock has occurred in the Southern and Western parts of the U.S., where air conditioning loads are large. Trends in household size, lifestyle, and age of household occupants also influence equipment ownership and daily usage patterns.

- Economic activity: Economic trends are tied partly to demographics, but also to business cycles and regional developments. Strong economic growth in a particular region will lead to more building construction and migration to that area, thereby increasing total electricity use and peak demand. The nature of economic growth (e.g., whether caused by relatively more or less energyintensive industries) also affects electricity use. The construction of new subdivisions, commercial facilities, or industries in rapidly growing localities can cause local peak load problems in addition to contributing potentially to the system coincident peak load.

- Equipment ownership: Equipment and building ownership trends can affect peak demand. For example, large purchases of room air conditioners during a heat wave can have a measurable effect on a utility's summer peak demand. Another example would be the trend towards larger commercial buildings that are dominated by internal loads and that require cooling all year round in many climates. For many appliances, the saturation of electric products continues to increase, which can drive up electricity use even as individual appliances are becoming more efficient.

- Technology choice: Adoption of new technology in existing end-uses can affect peak demand. The rising popularity of the flat-panel Liquid Crystal Display (LCD) screens is one example of this phenomenon, where this new technology uses one-third to one-half as much power as the Cathode Ray Tube that it replaces.

- Usage behavior: How people operate buildings and use appliances matters. The California electricity crisis in Summer 2001 was ameliorated in part because of price rises, in part because of changes in end-user behavior brought about by advertising by the state and the utilities, and in part because of heightened awareness of the crisis from all the news media attention (Goldman et al. 2002).

- Designer/installer behavior: The way technology is designed and installed can have important implications. Over-sizing of equipment, which is common in heating and cooling systems, can affect efficiency of equipment at time of system peak. Poor design and poor installation practice (for example, affecting the location and quality of ducts) can make a system inefficient, independent of the equipment efficiency.

- Government \& utility policies: Most implementation policies that affect the efficiency of buildings and equipment can also influence peak demand, as can utility regulation regimes and the structure of utility tariffs. Equipment efficiency 
standards, building codes, voluntary programs (like the EPA/DOE ENERGY STAR program), government procurement, and utility rebate programs all can have an effect in the short to medium term. Government Research and Development (R\&D) can have a longer-term effect on peak demand, by making higher efficiency options available that would not have existed in the absence of the R\&D (or by accelerating the availability of such technologies).

Figure 1 shows an example of a peak demand curve, taken from Brown and Koomey (2002). This curve is for the summer peak day in California in 1999, and it shows that the highest load was about twice the lowest load on that day. The graph demonstrates the importance of residential and commercial air conditioning and commercial lighting to the maximum demand on that day (those three end-uses account for about $40 \%$ of total peak load during the peak hours).

Total summer peak demand in the U.S. was about $700 \mathrm{GW}$ in 2001, as reported by the North-American Electric Reliability Council (NERC 2001). Typical winter peak demands for the U.S. are something over $600 \mathrm{GW} .^{1}$

\section{WHAT ARE THE KEY PEAK DEMAND ISSUES?}

\section{WHAT STRATEGIES ARE USED TO AFFECT PEAK DEMAND?}

Table 1 shows five major strategies that can affect utility peak demand:

- Load reducing strategies are those that reduce service demands without affecting the economic benefit derived from that energy use, such as load controls for buildings and equipment, and behavioral changes such as turning off lights. These measures are distinct from load shifting and efficiency technologies.

In principle, the reduction in energy services may or may not actually result in a loss of economic value. For example, if a light is left on when no one is in the room, shutting it off reduces demand for energy services, but does not reduce the economic benefit derived from lighting. On the other hand, if a load reducing technology led to a much hotter office building, then worker productivity could be affected and a loss to society could result. We only focus on those options that reduce service demands without affecting economic benefit in our list in Table 1.

- Load shifting strategies are those that involve shifting loads to off peak periods, using energy storage or smart controls. Thermal (cooling) storage systems are often used by customers who have high demand charges, or time-of-use or realtime rate schedules. These systems make ice during off-peak times and use that ice to cool the building during peak times, thus shifting the electricity load.

\footnotetext{
1 These reported loads are the sum of the coincident peak demands for the various regions making up NERC, but they are not the coincident peak demand that would result if the U.S system were completely integrated.
} 


\section{Figure 1: California 1999 Summer Peak-day End-use Load (GW): 10 largest coincident building-sector end-uses and non-building sectors}

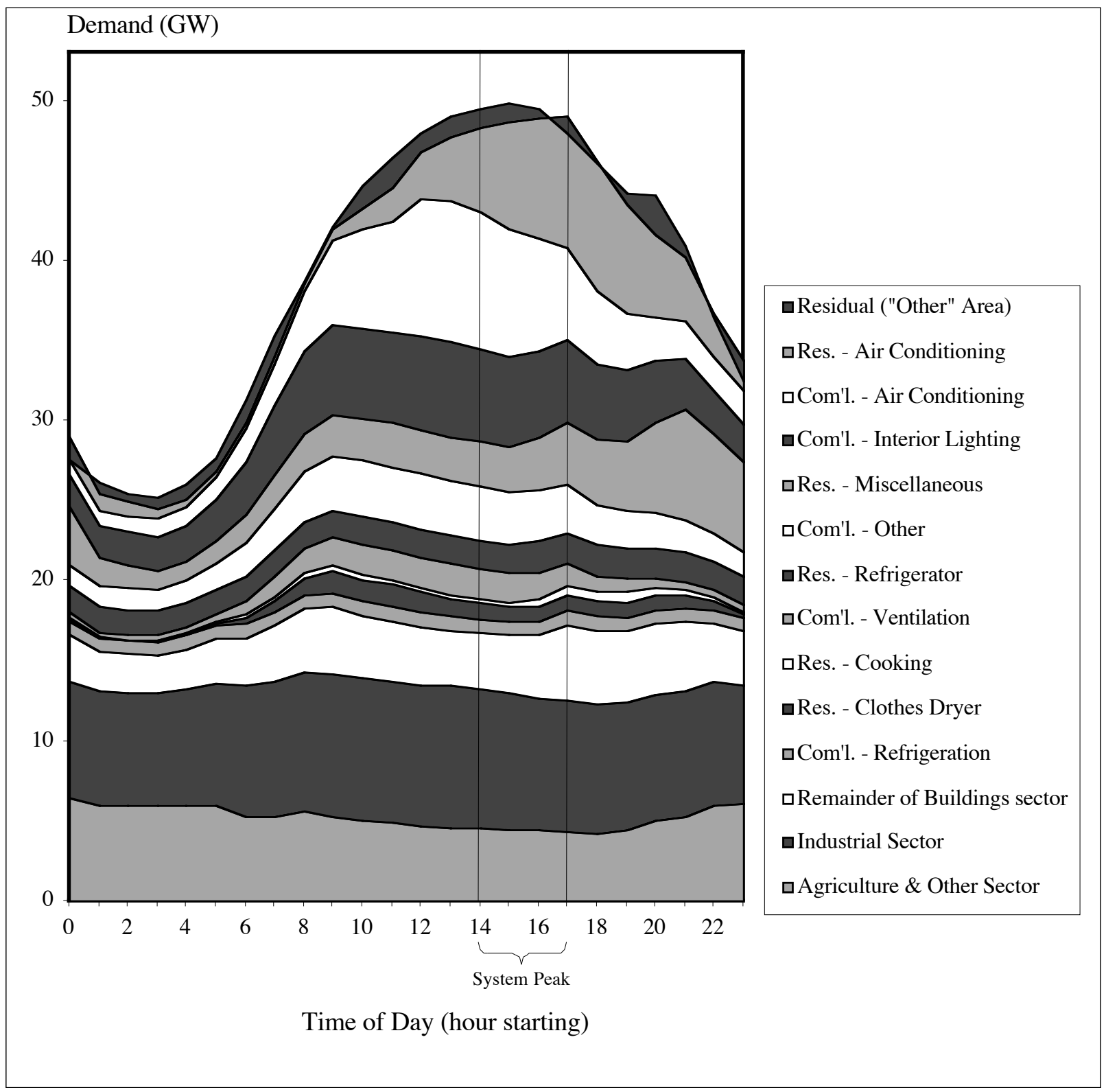

Notes: The ten largest coincident building-sector end uses are shown separately, while the smaller building end uses are aggregated together in "Remainder of Buildings Sector." The end uses are ordered the same vertically in the graph and the legend. Res. = residential buildings, Com'l. = commercial buildings. The non-building sectors are shown as sectoral totals. Thus, the buildings sector accounts for all but the bottom two segments of the graph. The Residual (top-most segment) is the difference between FERC system loads and the CEC forecasting model outputs. This difference is mainly due to small utilities not included in the CEC forecasting model. The "Agriculture \& Other" sector includes water pumping, transportation and street lighting.

Source: LBNL analysis of CEC and FERC data (Brown and Koomey 2002). 
Table 1: Categories and examples of strategies that can affect peak demand

\begin{tabular}{|c|c|}
\hline Load reducing strategies & Load shifting strategies \\
\hline $\begin{array}{l}\text { Load control glazings } \\
\text { Daylighting } \\
\text { Lighting and AC controls } \\
\text { Better building siting } \\
\text { High albedo roofing materials } \\
\text { Shading } \\
\text { Efficient humidity control } \\
\text { Behavioral changes (turning off the lights) } \\
\text { Energy management systems } \\
\text { Building commissioning } \\
\text { Weatherization }\end{array}$ & $\begin{array}{l}\text { Real time control of power use (grid interactive } \\
\text { price response) } \\
\text { Energy management systems } \\
\text { Thermal storage (e.g. CEC's precooling of } \\
\text { building prior to peak) } \\
\text { Waste heat recovery } \\
\text { Appliance and water heater timers }\end{array}$ \\
\hline High efficiency buildings \& equipment & Fuel switching to natural gas \\
\hline $\begin{array}{l}\text { Heating } \\
\text { Cooling } \\
\text { Lighting } \\
\text { Heat pump water heaters } \\
\text { Refrigeration } \\
\text { Others } \\
\text { Building commissioning } \\
\text { Weatherization }\end{array}$ & $\begin{array}{l}\text { Heating } \\
\text { Cooling } \\
\text { Water heating } \\
\text { Cooking } \\
\text { Clothes dryers }\end{array}$ \\
\hline \multicolumn{2}{|c|}{ On-site heat and electricity generation } \\
\hline $\begin{array}{l}\text { Building integrated photovoltaics } \\
\text { Fuel cells } \\
\text { Microturbines } \\
\text { Cogeneration } \\
\text { Microgrids } \\
\end{array}$ & $\begin{array}{l}\text { Solar water heating } \\
\text { Solar pool heating; } \\
\text { Passive/active solar space heating } \\
\text { Geothermal heat pumps }\end{array}$ \\
\hline
\end{tabular}

During the electricity crisis in California, the California Energy Commission (CEC) advocated an even simpler form of thermal storage, where building owners would cool their buildings down in the morning, and allow them to "coast" through the afternoon at a higher thermostat setpoint, thus effectively shifting the load to the off peak times. Heat storage systems are used in winter-peaking areas. In European countries, where time-of-use rates are commonplace, many residential appliances have built-in timers that allow them to be operated in offpeak hours.

- High efficiency equipment reduces the energy needed to deliver a given level of energy services, or (equivalently) produces more energy services per unit of energy and demand input. For example, high efficiency electronic ballasts can reduce electricity use and peak demand by about one-quarter compared to conventional magnetically-ballasted lighting technologies if combined with more efficient lamps.

- Fuel switching from electricity to direct use of natural gas can be effective in reducing peak demands from commercial air conditioning, and all forms of electric water heating and cooking. In utilities in cold climates, converting 
electric heating to natural gas can also reduce winter peaks. Measures in this category can be quite controversial because of the hotly competitive nature of the markets for direct use of electricity and natural gas.

- On-site energy generation reduces the demands seen by the utility grid, although it does require additional energy input (usually natural gas or biomass). On-site cogeneration can reduce total energy consumption when the waste heat from the electricity generation is used to displace heat from other sources (Krause et al. 1994). On-site generation using wind and photovoltaics is becoming increasingly common.

Each of these strategies have been or could be promoted by the Department of Energy (DOE) to affect peak demand. DOE's Office of Building Technology, State and Community Programs (BTS) has created a vision of the " $120 \%$ house" that would be a net annual contributor of electricity to the grid. Such a house would draw upon load reducing strategies, high efficiency equipment, and on-site energy generation (fuel cells, microturbines, photovoltaics, and potentially other renewable technologies). While this advanced house would certainly have lower peak demands than would a conventional house, it still could draw power during times of peak demand, depending on the configuration of the on-site generation technology.

\section{WHAT POLICIES CAN BE USED TO AFFECT PEAK DEMAND?}

We divide policies that affect peak demand into four main categories: those that promote innovation, those that enhance education, those that improve motivation, and those that mandate certain changes that would not occur otherwise. We treat each of these below.

- Innovation: $\mathrm{R} \& \mathrm{D}$ is a critically important policy for the medium to longer term. Peak demand has only occasionally influenced R\&D directions, but a focus on R\&D can lead to technology or policy innovations that will substantially affect peak demand. R\&D includes design of individual technologies and also system design and interaction effects.

- Education: Information and training is intended to affect technology choice, installation practice and usage behavior. Voluntary actions include the DOE/EPA ENERGY STAR labeling program, technology procurement initiatives by government and business, and government exhortations to turn off the lights and adjust the thermostat. Such voluntary programs have proven especially effective when they influence the manufacturers of mass-produced products like computers or TVs. Government leadership can also play a role, when the government itself decides to set guidelines for its facilities that are sometimes emulated by the private sector. DOE's Outreach/partnering programs supply technical support and funding for weatherization programs, and state energy education and outreach activities.

- Motivation: Incentives/pricing strategies include utility rebates/resource acquisition, modifying utility regulatory structure/incentives, and pricing/metering 
strategies (including time-of-day, real-time, interruptible, and weather-linked prices). Utility rebates are given directly to customers and manufacturers of energy using equipment to promote more efficient products, while incentives can also be given to utilities to encourage them to promote efficiency by their customers. Pricing strategies will grow in importance over time as metering technology drops in price and grows in sophistication. Even relatively crude pricing policies, such as various rebate programs and significantly increased block rates, in conjunction with widespread publicity and the threat of blackouts, seem to have had an important effect on California's electricity demand during the summer of 2001 (Goldman et al. 2002). Over 30\% of households reduced electricity consumption by $20 \%$ or more compared to the same months in the previous year.

Utility rebates to customers who reduced peak demand were commonplace before utility restructuring. As the utility industry moves away from the traditional forms of regulation, pricing strategies could displace utility rebates for those customers with some kind of time-differentiated pricing. Because most customers will not have such pricing for many years, utility rebates (and the peak demand issue in particular) will still be important for years to come.

- Mandates: Mandatory actions include specifying test procedures for FTC EnergyGuide labels, appliance \& equipment standards, building codes, and state implementation plans. Equipment standards have mainly been handled by the Federal government in the past decade, but states (like California) are beginning to take action for products not currently regulated by the Federal standards. Building codes are predominantly the concern of state and local authorities, although the Federal government continues to fund enabling research that makes implementing those codes easier for states and localities. State implementation plans are mandated under the Clean Air Act, but achieving those mandated pollution reductions can be achieved by states and localities using various types of programs, including any of the others discussed below. Most efforts to date have focused on energy; increased attention to peak demand is warranted, especially because times of peak electrical load also coincide with times of poor air quality.

Each of these policies have been successfully used at various times and places, and each has a role to play in any successful efforts to develop, deploy, and promote new technologies to reduce peak demand.

\section{WHAT ARE THE SEASONAL ASPECTS OF ELECTRIC PEAK DEMAND?}

Peak demand issues vary by season. In summer peaking utilities, cooling and lighting loads dominate, as shown in Figure 1 (above). Most U.S. regions are summer peaking, and the focus of most analysis therefore is on those end-uses. In winter peaking utilities, electric resistance heating tends to drive peak demands, although lighting and other end uses typically also play a role. Heat pumps often have electric resistance backup, so a very cold period can result in substantial use of that backup source, thus exacerbating winter peak issues. Seasonal supply-side factors can play a role in reliability concerns, 
because some generation resources, such as hydropower, are also affected by climatic conditions that drive peak load. For some generating resources and loads, seasonal factors can compound or mitigate peak load problems. For example, hot, dry conditions reduce hydro availability while increasing air conditioning loads. Alternatively, high solar insolation can increase both air conditioning loads and electricity output from photovoltaic panels. Regional and local reliability can be compromised because transmission lines lose capacity as the ambient temperature increases.

\section{WHAT ARE THE GEOGRAPHIC COMPONENTS OF THE ISSUE?}

Geography plays a key role in peak demand. Geography is important because of its relationship to weather and climate, but also because settlement patterns and siting constraints for generation and transmission lines have a geographic component as well.

- Weather and climate: Weather and climate affect the shape of load curves. Air conditioning load curves are spread more evenly over each day in Mississippi, with its hot and humid summers, than in California, where summer days are hot and dry and nights are often cool.

- Settlement patterns: Much of the housing growth in the U.S. over the past few decades has occurred in the southern and western U.S., where air conditioning is ubiquitous and the electricity consumption associated with air conditioning is large on a per household basis. Such trends in settlement patterns have obvious implications for peak demand growth.

- Transmission, distribution, and generation siting constraints: The U.S. electricity grid is not a national one. Most regions of the North American Electric Reliability Council have transmission capacity constraints to other regions. In addition, local constraints on distribution and generation facilities, mainly caused by siting constraints, can contribute to local outages in extreme circumstances (Orans et al. 1992).

The geographic variability of peak load introduces significant complexity to the analysis of this problem. Some of these geographic issues are amenable to treatment using geographic information systems, also known as GIS (May et al. 1996). Such computer tools are becoming more widely used as analysis and evaluation of program impact shifts from calculations based on national averages to those based on statistically representative samples of households and commercial buildings (see, for example, (US DOE 2000)). Utilities have made wide use of GIS for analyzing siting issues related to construction of transmission, distribution, and generation facilities, and these same tools can be applied to ameliorating peak demand problems, but have not thus far been used for that purpose.

\section{ARE THERE PEAK DEMAND ISSUES FOR NATURAL GAS?}

There also may be issues affecting the supply of natural gas or oil, either to end-users or to utilities. For example, a shortage of natural gas to a particular region could result in more residences using backup electric resistance heating in winter, thus increasing electricity demand and worsening the supply/demand imbalance. Such a shortage could 
also affect the cost of natural gas-fired electricity generation from the utility or from its industrial customers, also exacerbating the electricity supply/demand imbalance. These fuel shortages can be seasonal, or could be related to transmission and distribution constraints brought about either by physical limitations or by manipulation by the few large firms who typically control pipelines into a given region. They can also be related to larger global energy developments, such as an oil price shock, or to unexpected new uses of natural gas that arise from newly sited cogeneration facilities or new energy service demands (e.g. gas barbeques, outdoor gas lighting, fireplaces). Such new demands can be the result of clean air regulations, so this is yet another point where policies can affect the peak electricity demand issue.

\section{WHAT ARE THE KEY RESEARCH QUESTIONS?}

There are of course many research issues related to new technologies and strategies for reducing peak demand. These issues can be split into conventional and behavioral ones. Conventional R\&D, which has been treated extensively in many DOE reports, focuses on developing new technologies. For peak demand, important new technologies could fall into any of the areas treated in Table 1. The detailed issues around each of these technologies are too numerous to cover here, but they are presented in various DOE reports found at <http://www.eren.doe.gov/>.

Behavioral issues have been less extensively treated in the literature than have the conventional technical issues, so we focus on these issues here. The most important behavioral questions fall into three areas: technology choices of consumers, usage behavior of consumers, and the response of those same customers to time-of-use or realtime pricing signals. We treat each of these in turn:

- Technology choice and building design: Much of the program evaluation work for demand-side programs run by electric utilities has focused on the issue of the response of customers to incentives to purchase more efficient equipment (Eto et al. 1994, Eto et al. 1995) or to voluntary labeling programs (Horowitz 2001, Webber et al. 2000). There is also a significant literature on incentives for load shifting technologies, but the program evaluation studies on the incentives for other types of equipment (load reducing, fuel switching, and on-site generation) are few and far between. Much has been learned in the past two decades about how to use these programs effectively, but there are still many questions to be answered about the best ways to achieve high adoption rates, low free ridership, and low implementation costs. The complexities of successfully influencing building design also make more research in this area imperative.

- Usage behavior: One of the unexpected events of the California electricity crisis was the strong behavioral response exhibited by consumers in the face of strong exhortations from the California state government to conserve (Goldman et al. 2002). This strategy had not been tried since the late 1970s, and in contrast to the mixed success of the U.S. government's requests at that time to drive less and turn down the thermostat, the California campaign was a major reason why there were few if any blackouts in the summer of 2001. One of the key social science 
questions relates to the conditions under which such exhortations will be successful. Another involves the question of persistence: how many of the behaviors induced by exhortation will remain in place after the crisis has passed (i.e., can behavioral changes be as persistent as investments in energy efficiency, transmission lines, and distribution infrastructure)? Finally can the electricity system planners tap consumers' non-economic motivations (e.g., their desire for environmental protection) reliably and effectively?

- Time-varying price signals: The response of electricity customers to price signals is highly uncertain, but enabling such response has the potential to transform radically the way the electricity system operates (Warwick 2002). Demand is now essentially inelastic in the short run-the prices customers are charged do not reflect the time-varying cost of generating electricity at peak times (with the exception of some large customers who have both real-time pricing and/or interruptible rates). Before time-varying price signals will achieve widespread influence, a large number of facilities will need to install appropriate meters and purchase appliances and equipment that can respond automatically to changing prices. California is conducting a pilot program of this type, but the state is still years away from widespread adoption of such technology. The question of what kind of response such technology will evoke still looms large in any assessment of how peak demand issues will be treated in the future. Users will need to learn how to program their systems. There's also research needed on the "human factors" aspect of these technologies, so that they achieve the desired results.

Because peak demand is directly linked to human behavior, the social science dimension must be addressed in any successful assessment of peak demand issues.

\section{WHAT IS THE STATE OF DATA ON PEAK DEMAND IN BUILDINGS?}

Significant research was conducted on peak demand issues prior to 1993, but little has been done in the past decade, in large part because electric capacity had been more than adequate to meet demand in almost all regions during this period. In addition, state-bystate restructuring of the electric utility industry has led many utilities to classify more and more data proprietary and confidential, limiting the amount of publicly available data still further. The events of 2000 and 2001 in California have again focused attention on peak demand, and in particular the potential contribution of technologies and policies to affecting peak demand to minimize economic disruptions when supply and demand are out of balance. In the dynamic environment of the next decade, ongoing data collection and analysis are needed nationwide. To realize this potential will require renewed attention to data collection in this area.

Many utilities collect load data by customer class for use in rate-setting proceedings (Sorooshian-Tafti 1989) and post it to their web sites, but it has been many years since measurements of end-use load shapes were widespread (CEED 1993). The data collected have often covered individual end-uses such as lighting (CEC 1999), cooling, and water heating (Ontario Hydro 1984). A few studies have been more comprehensive for the residential (Brodsky and McNicoll 1987, Eto and Moezzi 1993, Ruderman et al. 1989) 
and commercial (ADM Associates 1989, Kasmar 1992, Pratt et al. 1990) sectors. Some of these data have made their way into computer models of hourly loads (EPRI 1993, McMahon et al. 1987, Ruderman and Levine 1984). Very few studies have measured end-use load savings in a systematic way, which is a much more difficult task, but it is essential for characterizing the peak demand impacts of efficiency options and for comparing those options to power plants (Nadel et al. 2000). Finally, the estimation of impacts of those load reductions on electric utility systems is another important component of a comprehensive analysis (Agras et al. 2001, Energy Analysis Program 1984, Eto et al. 1984a, Eto et al. 1984b, Eto et al. 1986a, Eto et al. 1986b, Eto et al. 1986c, Eto et al. 1988, Eto et al. 1989), but it is often neglected.

The data needed include both baseline measurements and measured savings from peak load reducing options. Hourly load shape data are the most useful, but are also the most expensive to collect and most difficult to use. To create statistically representative load shapes for buildings at the end-use level requires hourly sub-metering of individual circuits in hundreds of buildings. Such efforts are of course expensive and time consuming, and other approaches (like conditional demand analysis) have been used to supplement such metered data. There's still no real substitute for metering, however. There are some hybrid metering/analysis approaches, such as non-intrusive load monitoring, that offer the promise of lower cost, but these have not become widespread. Also, widespread adoption of interval meters for real-time billing purposes could serve as a rich new source of load data.

Load shape data can be aggregated in various ways to make their collection and use more straightforward. The conservation load factor (CLF) is a one-parameter summary of load shape characteristics that relates the average demand savings to the peak load savings from an efficiency measure. The CLF is useful because it allows straightforward comparisons between supply and demand technologies (it is analogous to the capacity factor for a power plant) and because it is a compact way to summarize load shape characteristics for efficiency options. The original work on this approach created CLFs for both technologies (Koomey et al. 1990b) and efficiency programs (Koomey et al. 1990a), but the scope of that work was limited by available data.

Additional data are also needed on the costs and effectiveness of technologies and programs for reducing, shifting, or otherwise ameliorating peak demand. These data should be collected as a matter of course for evaluating the cost effectiveness of such programs, but they are not always compiled.

\section{WHO ARE THE KEY STAKEHOLDERS?}

Many different institutions and individuals have an interest in peak demand issues, including electric utilities, appliance manufacturers, building developers, DOE (including the Federal Energy Management Program, FEMP), EPA, the National Institute of Standards and Technology (NIST), the Peak Load Management Alliance (http://www.peaklma.com), the North American Electric Reliability Council (http://www.nerc.com/), consumers, electricity-service providers, federal and state regulators, legislators, and various non-governmental organizations. There is no one 
organization responsible for all facets of this issue, which makes addressing it that much more difficult.

\section{IS THERE A UNIQUE FEDERAL ROLE?}

The peak demand issue is dominated by misplaced incentives. The majority of electricity users (the smaller ones) do not pay time-differentiated electricity prices, so they do not bear the cost of peak demand, and therefore do not demand energy-using equipment that reduces peak demand. Even the larger customers face misplaced incentives. For example, large buildings usually pay demand charges based on their peak demand, but those large buildings are often made up of many smaller tenants that are not separately metered and do not themselves ever see the demand charge except in some fixed monthly utilities fee. These misplaced incentives are one important basis for addressing this issue.

Because of their keen financial interest in minimizing peak demand, utilities have traditionally led the charge on treating the peak demand issue, but there are some areas that only the Federal government can address. In particular, changes in government programs like minimum efficiency standards, test procedures, FTC EnergyGuide labels, and DOE/EPA ENERGY STAR voluntary programs are best undertaken at the federal level. The Federal government can also encourage states to regulate utilities in a way that fosters price-responsive electricity demand. Funding long-term R\&D is also generally acknowledged to be an appropriate role for the Federal government. Finally, data collection, compilation, and analysis activities are most cost-effectively conducted at the Federal level or in collaboration with state efforts, since there are large economies of scale in such efforts, and individual states or utilities have little incentive to compile and make available information from other regions.

\section{WHICH POTENTIAL SOLUTIONS FALL UNDER THE PURVIEW OF DOE?}

We list here broad categories of potential policy options, including mandatory actions, voluntary actions, incentives/pricing strategies, $R \& D$, and data collection $\&$ analysis, and we focus the discussion on solutions that DOE/BTS is particularly well suited to implement (or that it already has underway).

- Mandatory actions: BTS could promote the modification of future test procedures, efficiency standards and building codes for key end-uses to better reflect peak demand concerns. For example, Central Air Conditioner (CAC) efficiencies could be specified both as a seasonal energy efficiency ratio (SEER) and also as an energy efficiency ratio (EER), which would more accurately measure the impact of an efficient CAC on peak demand. FEMP could set an example by requiring that Federal facilities meet such guidelines even before the regulatory review process for standards is completed. If test procedures were to be updated to treat peak demand, there are presumably other corrections and additions that could be made simultaneously (e.g. measurement of standby power) to improve the test procedures. 
- Voluntary actions: For the DOE/EPA ENERGY STAR products (and related procurement programs), the specifications for qualifying products are periodically made more stringent, and the next phase of such revisions could explicitly specify criteria that would help reduce peak demand. DOE can assist states and utilities to develop successful exhortations to reduce peak load by making information widely available on energy and peak demand impacts from load-reducing technologies.

- Incentives/pricing strategies (including giving utility rebates for peak reductions/load shifting and changing utility regulation to give incentives to utilities for implementing efficiency) are largely under the control of utilities and state regulators. BTS may have a role in collecting data on the effectiveness of such efforts because those efforts affect the adoption of technologies in buildings. BTS can also promote the adoption of regulatory policies that encourage priceresponsive demand technologies and pilot programs.

- Outreach/partnering is another important area of DOE/BTS activities. DOE's Weatherization Assistance Program and State Energy Program currently don't focus much on peak demand, but could in principle be altered to do so to a greater degree than in the past.

- $R \& D$ is a critically important policy for the medium to longer term. Peak demand has only occasionally influenced $R \& D$ directions. Product manufacturers have little or no incentive to fund $R \& D$ to reduce peak demand, because the consequences of their failure to modify their product designs are borne not by their own customers (who buy the product but likely don't have timedifferentiated pricing) but by utilities and society as a whole. It is especially important to identify new R\&D areas that are not currently part of EERE's portfolio but that show promise for reducing peak demand for certain end uses. For example, BTS may have a role in developing the metering and new equipment control technologies that will allow time-varying price regimes for electricity to finally achieve their full potential - far too little recent work has been done in this area, and the potential long-term payoff is huge. It will require coordination with other parts of DOE who focus mainly on the utility side of the meter and with private interests developing standardized communications protocols. R\&D to develop modeling tools to predict peak demand impacts from different measures may also be needed.

- Data collection and analysis for energy efficiency technologies has traditionally been an important area for BTS, and the peak demand issue is no exception. As discussed above, few measured load data have been collected at the end-use level since the early 1990s, and that lack has been sorely felt. The data that now exist are either out-dated or proprietary, and a public sector entity to promote the collection of non-proprietary data is sorely needed. The introduction of real-time or time-of-use pricing and control has great potential, not just for ameliorating the peak demand problem but also for making available large amounts of timevarying end-use load data. Both baseline and peak savings data are needed - the 
savings data that do exist are sparse. Other data are needed on technical costs of measures to ameliorate peak demand, as well as data evaluating the costs and effectiveness of policies and programs of this nature.

One concrete action BTS can take on data collection is to require that all future BTS-funded analyses of energy efficiency technologies calculate peak savings as well as energy savings, technology costs, and program costs, using a clearly documented methodology. The appliance standards analyses already contain such estimates, but BTS sponsors much other research that does not always assess peak demand savings. Compiling these data in the form of load curves, load savings curves, and conservation load factors would assist future analysts in analyzing potential impacts of proposed policies (those results are now scattered among many different technical reports).

DOE is in a unique position to solve some of the key issues surrounding peak demand, by affecting policy design, funding research, and collecting data.

\section{Conclusions}

In the short run, DOE funding of deployment activities on peak demand can help society achieve a more economically efficient balance between investments in supply and demand-side technologies. DOE policies can promote implementation of key technologies to ameliorate peak demand, through government purchasing, technology demonstrations, and improvements in test procedures, efficiency standards, and labeling programs. In the long run, $R \& D$ is probably the most important single leverage point for DOE to influence the peak demand issue. Technologies for time-varying price response hold great potential for radically altering the way people use electricity in buildings, but are decades away from widespread use, so DOE R\&D and expertise can make a real difference here.

In both the short and long run, data compilation and analysis are critical to success. Existing data on peak demand issues are largely outdated, and those data that are not obsolete are either proprietary or scattered in many different technical reports. DOE has a unique and central role to play in compiling the data relevant to the peak demand issue, so that programs, policies, and technologies can be evaluated and improved over time.

\section{ACKNOWLEDGEMENTS}

This exploratory option paper was written at the request of Jerry Dion at the U.S. Department of Energy (DOE) Office of Building Technology, State and Community Programs. It is one of several white papers commissioned in 2002 exploring key issues of interest to this part of DOE. The authors would like to thank Jerry Dion for funding this work, and for his comments on various drafts. We would also like to thank the reviewers who contributed comments, including Merwin Brown (ORNL), Jeff Harris (LBNL), Don Jones (ORNL), Christy Herig (PNNL), Bruce Kinzey (PNNL), Jim McMahon (LBNL), Andrew Nicholls (PNNL), Max Sherman (LBNL), Carol Tombari (Mountain Energy Consultation), and Mike Warwick (NREL). While the authors did not 
adopt every suggested change, we read them all and included them when we felt they added or clarified information without significantly affecting the length or the purpose of the paper. Any omissions or errors are of course the responsibility of the authors.

Lawrence Berkeley National Laboratory supplies information to the U.S. Department of Energy to aid in DOE's decisionmaking processes, but it does not make those policy decisions. The opinions expressed in this report are those of the authors and do not necessarily represent those of DOE, LBNL, or the University of California.

This work was supported by the Office of Building Technology, State and Community Programs of the U.S. Department of Energy, under Contract No. DE-AC03-76SF00098. 


\section{REFERENCES}

ADM Associates. 1989. End-Use Metered Data for Commercial Buildings: Interim Report, Volume I. Rosemead, CA: Prepared for Southern California Edison Company by ADM Associates, Inc. April.

Agras, Jean, Heidi Ries, and Peter Larson. 2001. Benefits of Peak Load Reduction Resulting from the CAC Standard. Boulder, CO: Stratus Consulting, for the U.S. Department of Energy's National Renewable Energy Laboratory. Draft report, February 20.

Borenstein, Severin. 2001. The Trouble with Electricity Markets and California's Electricity Restructuring Disaster. Berkeley, CA: Program on Workable Energy Regulation (POWER), University of California Energy Institute (also forthcoming in Journal of Economic Perspectives). PWP-081. September 10. Available from World Wide Web: (http://www.haas.berkeley.edu/ borenste/CATrouble.pdf)

Brodsky, Joel B., and Susan E. McNicoll. 1987. Pacific Gas and Electric Company Residential Appliance Load Study, 1985-1986. SF, CA: PG\&E, Regulatory Cost of Service Department, Research Section. September.

Brown, Richard E., and Jonathan G. Koomey. 2002. "Electricity Use in California: Past Trends and Present Usage Patterns." Forthcoming in Energy Policy (also LBNL-47992).

CEC. 1999. Lighting Efficiency Technology Report: Volume I, California Baseline. Sacramento, CA: California Energy Commission. P400-98-004VI. September. Available from World Wide Web: (http://38.144.192.166/efficiency/lighting/VOLUME01.PDF)

CEED. 1993. Conference Proceedings. Proceedings of the Electric End-use Data Symposium: Current Endeavors and Future Directions. Adams's Mark Hotel, St. Louis, MO: Electric Power Research Institute, Center for Electric End-use Data. October 27-29.

Energy Analysis Program. 1984. The Detroit Edison Company. Financial Impacts on Utilities of Load Shape Changes Project: Stage I Summary Report. Lawrence Berkeley Laboratory. LBL-19750. June.

EPRI, Electric Power Research Institute. 1993. HELM User's Guide. Palo Alto, CA: EPRI. EPRI RP 2863-9. May.

Eto, Joe H., James E. McMahon, and Peter Chan. 1984a. The Pacific Gas and Electric Company. Financial Impacts on Utilities of Load Shape Changes Project: Stage II Summary Report. Lawrence Berkeley Laboratory. LBL-19751. June.

Eto, Joe H., James E. McMahon, and Peter Chan. 1984b. The Virginia Electric and Power Company. Financial Impacts on Utilities of Load Shape Changes Project: Stage III Summary Report. Lawrence Berkeley Laboratory. LBL-19752. December. 
Eto, Joe, Jonathan Koomey, James E. McMahon, and Peter Chan. 1986a. Financial Impacts on Utilities of Load Shape Changes: The Nevada Power Company. Lawrence Berkeley Laboratory. LBL-21597. April.

Eto, Joe, Jonathan Koomey, James E. McMahon, and Peter Chan. 1986b. Financial Impacts on Utilities of Load Shape Changes: The Texas Utilities Electric Company. Lawrence Berkeley Laboratory. LBL-21598. April.

Eto, Joe, Jonathan Koomey, James E. McMahon, and Peter Chan. 1986c. Financial Impacts on Utilities of Load Shape Changes: Thermal Integrity Measures for Residential Buildings; Texas Utilities Electric Company and Nevada Power Company. Lawrence Berkeley Laboratory. LBL-22627. May.

Eto, Joe, Jonathan Koomey, James McMahon, and Edward Kahn. 1988. "Integrated Analysis of Demand-Side Programs." IEEE Transactions on Power Systems. vol. 3, no. 4. pp. 1397.

Eto, Joe, James E. McMahon, Jonathan Koomey, Peter Chan, and Mark D. Levine. 1989. The Regional Impacts of the National Appliance Energy Conservation Act of 1987. Proceedings of the DSM Conference. Cincinnati, $\mathrm{OH}$ : May.

Eto, Joe, Edward Vine, Leslie Shown, Richard Sonnenblick, and Chris Payne. 1994. The Cost and Performance of Utility Commercial Lighting Programs. Lawrence Berkeley Laboratory. LBL-34967. May.

Eto, Joseph H., Suzi Kito, Leslie Shown, and Richard Sonnenblick. 1995. Where did the money go? The cost and performance of the largest commercial sector DSM programs. Berkeley, CA: Lawrence Berkeley Laboratory. LBL-38201. December.

Eto, Joseph H., and Mithra M. Moezzi. 1993. Analysis of PG\&E's Residential End-Use Metered Data to Improve Electricity Demand Forecasts-Final Report. Berkeley, CA: Lawrence Berkeley National Laboratory. LBL-34431. December.

Goldman, Charles A., Galen Barbose, and Joseph H. Eto. 2002. California customer load reductions during the electricity crisis: Did they help keep the lights on or dampen wholesale prices? Berkeley, CA: Lawrence Berkeley National Laboratory. DRAFT LBNL-49733. March.

Hope, Gordon, Roland Schoettle, and Richard Hammond. 2001. Operations Review of June 14, 2000 PG\&E Bay Area System Events Using Aempfast ${ }^{\circledR}$ Software: Final Report. Benicia, CA: Report Produced by Optimal Technologies, for Lawrence Berkeley National Laboratory and the California Energy Commission. October 3.

Horowitz, Marvin J. 2001. "Economic Indicators of Market Transformation: Energy Efficient Lighting and EPA's Green Lights." The Energy Journal. vol. 22, no. 4. Oct-Dec. pp. 95-122.

Kahn, Edward. 1988. Electric Utility Planning and Regulation. Washington, DC: American Council for an Energy-Efficient Economy. 
Kasmar, Jeff. 1992. End-Use Metering in Commercial Buildings: 1991 Summary Results. SF, CA: Prepared for Pacific Gas \& Electric Company by Regional Economic Research, Inc. November.

Koomey, Jonathan, Arthur Rosenfeld, and Ashok Gadgil. 1990a. Conservation Screening Curves to Compare Efficiency Investments to Power Plants: Applications to Commercial Sector Conservation Programs. Proceedings of the 1990 ACEEE Summer Study on Energy Efficiency in Buildings. Asilomar, CA: American Council for an Energy Efficient Economy.

Koomey, Jonathan, Arthur H. Rosenfeld, and Ashok K. Gadgil. 1990b. "Conservation Screening Curves to Compare Efficiency Investments to Power Plants." Energy Policy. vol. 18 , no. 8. October. pp. 774-782.

Krause, Florentin, Jonathan Koomey, Hans Becht, David Olivier, Giuseppe Onufrio, and Pierre Radanne. 1994. Fossil Generation: The Cost and Potential of Low-Carbon Resource Options in Western Europe. El Cerrito, CA: International Project for Sustainable Energy Paths.

May, Carol, Rich Brown, Peter Banwell, Kate Foery, Stephen Offutt, and Annette Wilson. 1996. Increasing the Use of Energy-Efficient HVAC Equipment in Homes Through the Use of Voluntary and Profitable Pollution Prevention Programs. Proceedings of the 1996 ACEEE Summer Study on Energy Efficiency in Buildings. Asilomar, CA: American Council for an Energy Efficient Economy, Washington DC.

McMahon, James E. , Peter Chan, Joseph Eto, Jon Koomey, Mark Levine, Chris Pignone, and Henry Ruderman. 1987. "The LBL Residential Energy and Hourly Demand Models." In Strategic Planning in Energy and Resources. Edited by B. e. a. Lev. Holland: Elsevier Science Publishers B.V. 205-212 pp.

Nadel, Steven, Fred Gordon, and Chris Neme. 2000. Using Targeted Energy Efficiency Programs to Reduce Peak Electrical Demand and Address Electric System Reliability Problems. Washington, DC: American Council for an Energy Efficient Economy. U008. November.

NERC, North-American Electric Reliability Council. 2001. Reliability Assessment 20012010: The Reliability of Bulk Electric Systems in North America. NERC. October 16.

Ontario Hydro. 1984. Development of Residential Hot Water Use Patterns for Ontario Hydro. Toronto, Ontario, Canada: Report for the American Society of Heating, Refrigeration, and Air-conditioning Engineers, by the Research Division of Ontario Hydro. RP-430. December.

Orans, Ren, C. K. Woo, J. N. Swisher, Wiersma, and B. Horii. 1992. Targeting DSM for Transmission and Distribution Benefits: A Case Study of PG\&E's Delta District. Palo Alto, CA: Electric Power Research Institute. TR-100487. May. 
Osborn, Julie, and Cornelia Kawann. 2001. Reliability of the U.S. Electric System -Recent Trends and Current Issues. Berkeley, CA: Lawrence Berkeley Laboratory. LBNL-47043. August.

Pratt, R. G., M. A. Williamson, E. E. Richman, and N. E. Miller. 1990. Commercial Equipment Loads End-Use Load and Consumer Assessment Program (ELCAP). Richland, WA: Prepared by the Pacific Northwest Laboratory for the Bonneville Power Administration. DOE/BP-13795-24. July.

Ruderman, Henry, Joseph H. Eto, Kristin Heinemier, A. Golan, and David J. Wood. 1989. Residential End-Use Load Shape Data Analysis: Final Report. Berkeley, CA: Lawrence Berkeley National Laboratory. LBNL-27114. April.

Ruderman, Henry, and Mark D. Levine. 1984. The Residential Hourly and Peak Demand Model: Description and Validation. Lawrence Berkeley Laboratory. LBL-18698. August.

Shugar, Daniel S. 1990. Photovoltaics in the Utility Distribution System: The Evaluation of System and Distributed Benefits. Proceedings of the The 21st IEEE Photovoltaic Specialists Conference. Kissimmee, FL. May.:

Sorooshian-Tafti, Cyrus. 1989. 1987 Customer Sector Load Profile Estimates. Tariffs Division, Revenue Requirements Department, Southern California Edison Co. January 1989.

US DOE. 2000. Technical Support Document: Energy Efficiency Standards for Consumer Products: Residential Central Air Conditioners and Heat Pumps. Washington, DC: U.S. Department of Energy, Assistant Secretary, Energy Efficiency and Renewable Energy, Office of Building Research and Standards. October. Available from World Wide Web: (http://www.eren.doe.gov/buildings/codes standards/reports/cac hp tsd/)

Warwick, W. Michael. 2002. If Buildings Could Talk: How BTS Can Use Information Technology to Maximize Energy Efficiency in a Deregulated Environment. Richland, WA: Pacific Northwest National Laboratory. DRAFT. March 1.

Webber, Carrie A., Richard E. Brown, and Jonathan G. Koomey. 2000. "Savings Estimates for the ENERGY STAR Voluntary Labeling Program." Energy Policy. vol. 28, no. 15. December. pp. 1137-1150. 